\title{
The Influence of Price, Service, Quality, Costumer Satisfaction A Case Study of CV Duta Perkasa Pasuruan
}

\author{
Nurus Sobakh \\ UNIVERSITAS PGRI WIRANEGARA PASURUAN \\ Department of Economics Education, Faculty of Pedagogy and Psychology, Universitas PGRI Wiranegara \\ Pasuruan, Indonesia
}

\begin{abstract}
CV Duta Perkasa Pasuruan is mechanical and electrical basic materials CV to produce water pipe. The price of raw materials in this $\mathrm{CV}$ is relatively affordable. The company provides quality services. The consumers can feel satisfaction while they are buying. This study aims to analyze whether there is an effect of price and quality of service on consumer satisfaction in the CV Duta Perkasa of Pasuruan. The data used in this study are primary data obtained through distributing questionnaires to 100 respondents. The analytical method used is multiple linear regression analysis. The results of this study indicate that price does not have a significant effect on customer satisfaction with a significant value of $0.735>0.05$. Service Quality Variable has a significant influence on customer satisfaction which has a significant value of $0,000>0.05$. Simultaneously the price and quality of service together affect customer satisfaction with a significant value of $0,000>0.05$
\end{abstract}

Keywords: Price, Service Quality, Consumer Satisfaction

DOI: $10.7176 / \mathrm{JESD} / 11-16-19$

Publication date:August $31^{\text {st }} 2020$

\section{Introduction}

The mechanical and electrical industry is the biggest mainstay after oil and gas because it has favorable prospects for the future. Through the sector of a region can increase the original income of the region and it can also expand job opportunities. Indonesia has the potential to become one of the industrial areas in Pasuruan.

CV. Duta Perkasa Engineering is a local company engaged in the field of mechanical \& electrical, every industry to produce a product can not be separated from mechanical \& electrical work. CV. Duta Perkasa Engineering is basically a specialist in the work of Stainless Steel, Contractors and Equipment Distributors, $C V$. Duta Perkasa Engineering is also engaged in the field

of Manufacturing and Services, as a contractor from small factory packages to large factory packages . Cv Duta Perkasa has experienced in the field of piping product line (food grade) and piping line utility, Over time

Pasuruan is one of the largest industrial cities in East Java. In addition, Pasuruan City has a high investment potential, so that it can attract investors. According to Irsyad (2009) Pasuruan City is located in a low-lying area that has high security in terms of natural disasters. This potential is reflected in the wealth of industrial raw material production. One of the industrial areas that has its own uniqueness in the city Pleret. Pasuruan is a place that relies on the industry as an investor attraction.

CV Duta Perkasa Pasuruan has potential "stainless steel" branding . CV Duta Perkasa Pasuruan, which has been established since 2010, has a department consisting of two divisions, which include mechanical and electrical divisions with two divisions. CV Duta Perkasa Pasuruan always provides the best service from price and quality of service for customer satisfaction. .In addition, CV Duta Perkasa also has its own image for consumer satisfaction, both from local and foreign consumers.

Cv Duta Perkasa Pasuruan also provides supporting facilities for the convenience of customers with the construction of industrial water supply pipes. The facilities provided can be new offers that can be a determinant of customer satisfaction. The consumers in Duta Perkasa CV are mostly from outside Pasuruan City, for example from Surabaya, Jakarta, Solo and Bandung. The number of consumers who buy also determines the development of the industry in $\mathrm{CV}$ duta perkasa

It can be explained that the level of consumer purchases in CV Duta Perkasa has increased and decreased significantly in each month. This can be influenced by several factors namely price and quality of service and availability. A similar industry that is emerged in the city of Pasuruan Many people of Pasuruan opened widely. The development of the economy does not compete in the business world, so that each company must be able to provide satisfaction to consumers both in terms of price and quality of service. Many factors affect consumer satisfaction, one of them is price.

According to Chandra (2011) price is a form of value that can be exchanged for products and services with all components and a number of costs incurred by consumers. Cv Ambassador Mighty provides product prices of Rp. 200,000-Rp250,000 / pipe In addition to the importance of pricing in an industrial place, CV mighty ambassador must be able to apply the quality of services provided can provide satisfaction to consumers who visit. According to Chandra (2011) service quality is the company's ability to meet customer expectations and also if the 
service received or perceived is in accordance with expectations, then the quality is perceived well and can satisfy customers, conversely if the received is lower than the expected, then the quality is perceived poorly and unsatisfactorily.

The relation manager provided by the mighty ambassador $\mathrm{CV}$ is very helpful in conveying information about the scope of pipe sales. With the relation manage can help serve consumers who will make a pipe purchase.

The quality of this service aims to be able to get satisfaction in each consumer. Consumer satisfaction is one of the factors that can influence consumers to buy certain products. Therefore, each product must provide customer satisfaction to meet consumer expectations. According to Maulana (2006) consumer satisfaction can be felt after consumers compare their experiences in purchasing goods / services from sellers or providers of goods / services with the expectations of the buyers themselves. This expectation is formed through their first experience in buying goods / services, comments from friends, acquaintances, and the promises and information of marketers and competitors. Marketers who want to excel in competition must certainly pay attention to customer expectations and customer satisfaction.

The influence of customer satisfaction on the mighty ambassador CV Duta Perkasa on price and quality of service needs to be examined to determine the extent of the response of consumers to the mighty ambassador's CV Duta Perkasa and to know some important things that can be used as a development

Based on the conditions that have been explained, it is necessary to conduct a study on consumers in the CV of the mighty ambassador through matters relating to direct consumers. Thus, the authors are interested in conducting research in the mighty ambassador CV Duta Perkasa

According to Creswell (2018) states that the hypothesis is a temporary answer to the formulation of research problems, where the research problem formulation has been stated in the form of questions. The relationships between variables in this study are as follows:

According to Maulana (2006) explains that in essence the selection of a product is influenced by knowledge, income and beliefs and price policy can affect the human mindset, considering its activities by using this logic.

Based on the statement above it can be concluded that a price set price in accordance with field conditions can make consumers feel satisfied. Because a comparable price will affect consumer expectations indirectly. So consumers will feel satisfied buying a mighty ambassador CV. Therefore, the authors formulated the hypothesis as follows:

$\mathrm{H} 1$ : Price influences Consumer satisfaction in the mighty Ambassador CV

According to Maulana (2006) the quality and services provided by companies are very closely related to the satisfaction felt by consumers or visitors. Good service quality will attract consumers to buy again. In addition consumers will also recommend to others or about the services provided by the company. If the company provides a good quality of service and in accordance with the expectations of visitors, consumers will feel satisfied with what is felt. However, on the other hand if the services provided are not as expected by consumers , the dissatisfaction will be felt by consumers .

Based on the statement above it can be concluded that the quality of service in the company can affect customer satisfaction. So the quality of services provided must be good and clear and be able to provide a service that can provide needs that can be met directly, while in the ambassador's mighty CV .

$\mathrm{H}$ 2: Quality of service affects the satisfaction of consumers in the mighty ambassador cv .

The price is the total amount of costs that consumers need to spend to enjoy a product or service. Quality of service is the company's ability to meet customer expectations and also if the service received or felt is as expected, then the quality is perceived to be good to satisfy customers. Conversely, if what is received is lower than expected, then the quality is not met or not satisfied. Consumer satisfaction is the level of feeling someone after using a product / service that he feels with his expectations (Maulana, 2006).

Based on the statement above, it can be concluded that if the two independent variables price and service quality are both of good quality and in line with expectations or exceeding consumer prices while buying a product of a mighty ambassador dicv. This will trigger the emergence of perceived consumer satisfaction. Therefore, the authors formulate the research hypothesis as follows:

H3: Price and Service Quality influence Consumer Satisfaction in the mighty ambassador CV .

\section{Method}

The research location was done in one industrial area pasuruan City area, it is namely CV Duta Perkasa Pleret Pasuruan. This research continued from February 2020 to April 2020 .According to Sugiono (2018) research methods can be grouped into two methods namely, qualitative methods and quantitative methods. Qualitative methods can be interpreted as research methods based on positivist philosophy, used to examine populations or specific samples, collecting data using research instruments, analyzing quantitative / statistical data, with the aim of testing established hypotheses.

This study uses a quantitative research approach to test hypotheses or theories. The data used is related to the level of consumer satisfaction in the mighty ambassador $\mathrm{CV}$. 
Data collection that will be carried out as material for analysis in this study are primary data and secondary data. The following describes the two types of data.

According to (2018) primary data is data that can be obtained directly to the source (respondent). Primary data is needed to find out the response of respondents regarding the level of consumer satisfaction that is felt in the mighty ambassador $\mathrm{CV}$ which is seen from the price and quality of service. Primary data were obtained using data collection techniques as follows:

a. Interview

Creswell (2018) unstructured interview is a free interview where researchers do not use interview guidelines that have been arranged systematically and completely to collect information data about the general picture of the company and responses from respondents, because with this research researchers can communicate more flexibly with informants and obtain more detailed information.

b. Questionnaire

Questionnaire is a data collection technique that is done by giving a set of questions or written statements to respondents to be answered, (Creswell, 2018). Questionnaires are used to find out respondents' opinions, data obtained from population sampling and samples to be studied. The questionnaire aims to obtain correct information related to customer satisfaction that visits the mighty ambassador $\mathrm{CV}$ that is influenced by the price and quality of service.

Secondary data collection methods or procedures used in this study include:

Literature study according to Creswell (2018) is data collection with the aim to find out various knowledge or theories relating to research problems, derived from books, journals or other literature relevant to research.

This documentation is a source of data used for researchers to make support such as taking pictures, documentation and purchase prices for products purchased at the $\mathrm{CV}$ of the mighty ambassador and a general description where the research takes place.

The population used in this study is consumers who buy the mighty ambassador CV products.The sample is part of the number and characteristics possessed by the population, if a large population will not be taken all, then the sample to be taken from the population must be truly representative (represent) (Creswell, 2018). This research was conducted with 2 independent variables including price and service quality. While the dependent variable is customer satisfaction. The variables to be measured are translated into indicators with a Likert scale.

Research instruments that use a Likert scale can be created in checklist or multiple choice form (Creswell, 2018). In this research Likert scale will be presented in the form of a checklist. This study entitled the effect of price and quality of service on consumer satisfaction in the mighty ambassador of Pasuruan CV. In this case There are 3 instruments that need to be made namely:

Price variable (X1)

Service quality variable (X2)

Consumer satisfaction variable (Y)

The multiple linear regression model can be called a good model if the model meets the assumptions of data normality and is free from classical statistical assumptions of both multicollinearity and heterosecdasticity (Ghozali, 2018).

1. Multiple Linear Regression Analysis

According to Creswell (2018) multiple linear regression analysis is used to find out how much influence the independent variable is Price $\left(\mathrm{X}_{1}\right)$ and Service Quality $\left(\mathrm{X}_{2}\right)$ on the dependent variable that is customer satisfaction in the CV Duta Perkasa Y). The form of multiple linear regression equations are

$\mathrm{Y}=$ Consumer satisfaction in CV Duta Perkasa

$\mathrm{a}=$ constant

b 1 , b 2 = Regression Coefficient

$\mathrm{X} 1$ = Service Quality

$\mathrm{X} 2$ = Price

$\mathrm{e}=$ Prediction Error ( error term )

According Creswell (2018) double correlation ( multiple correlation) is a number that shows the direction and strength of the relationship between two independent variables together or more with the dependent variable. The formula for the multiple correlation coefficient is 2 (two) independent variables

If $\mathrm{F}_{\text {arithmetic }}>\mathrm{F}$ table, the independent variables together have a significant effect on the dependent variable.

If $\mathrm{F}_{\text {arithmetic }}<\mathrm{F}$ table, the independent variables together do not have a significant effect on the dependent variable. .In this study using two independent variables and one dependent variable. In conducting the $t$ test using the SPSS application program. The criteria for decision making with a significant level ()$=0.05$ are determined as follows:

a If $t_{\text {arithmetic }}>t_{\text {table, }}$, then the independent variables individually have a significant effect on the dependent variable

$\mathrm{bt}_{\text {count }}<\mathrm{t}_{\text {table }}$ : Then the independent variables individually do not have a significant effect on the dependent variable. 


\section{Results and Discussions}

Respondents in this study are consumers who buy in the mighty ambassador CV . And for sampling in this study as many as 100 respondents. In the questionnaire the independent variables are price (X1), Service Quality (X2) and for the dependent variable regarding customer satisfaction (Y). from descriptive respondents here that is to explain about the identity of respondents based on gender, age, address, education and profession, the reason for buying in the mighty ambassador cv. The following is a description of the respondent's identity data

Table 4.1 Descriptive respondents by gender

\begin{tabular}{ccc} 
No & Information & Number of Respondents \\
\hline 1 & Male & 75 \\
2 & Girl & 25 \\
\hline & amount & $\mathbf{1 0 0}$
\end{tabular}

Based on table 4.1 above from the results of the study 100 respondents showed that descriptive respondents based on gender showed more dominant is female respondents compared to male respondents with a total of 75 male respondents and the number of female respondents by 25 respondents.

2. Descriptive respondent based on age

Table 4.2 descriptive respondents by age

\begin{tabular}{ccc}
\hline No & Information & Number of Respondents \\
\hline 1 & $20-25$ years & 23 \\
2 & $26-35$ years old & 33 \\
3 & $36-45$ years & 21 \\
4 & $46-50$ years & 15 \\
5 & $51>$ Years & 28 \\
\hline & Amount & $\mathbf{1 0 0}$
\end{tabular}

Source: primary data, 2019

Based on table 4.2 above shows that descriptive consumers who visited CV Duta Perkasa more dominant age 26-35 years by 33 respondents. While the least age is $51>$ Years by 8 respondents.

Test instruments in the questionnaire can be used to find out valid and reliable data in the questionnaire under study. The quality of research instruments is determined by two criteria, namely validity and reliability. A data can be stated well if the instrument test results show a valid and reliable data statement. The following are the results of the instrument validity and reliability in this study:

Validity test is used to measure the validity or validity of a questionnaire. In this study conducted by comparing the value of $r_{\text {count }}$ with $r$ table, the number of samples used by 100 respondents with a significance level of 5 To get ${ }_{r}$ tables refer to the formula degree of freedom $(\mathrm{df})=\mathrm{n}-2$ with a significant $5 \%$ which gets the $\mathrm{r}_{\text {table }}$ calculation of 0.196 . Testing this validity can be declared valid if the correlation peason $>0.196$. instrument variable price, service quality and customer satisfaction are declared valid because for each pearson correlation

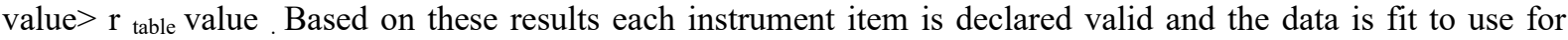
research.

The reliability test is carried out jointly on all questions or statements. If Crobach's Alpha value $>0.60$ then the data declared reliable (Sujarweni, 2015). In this there are two free and one variable dependent variable, this reliability test is done for each variable whether

The classic assumption test that must be met is residuals with normal distribution, multicollinearity and heteroscedasticity. The results of the classic assumption test in this study are as follows:

Analysis of the data in this study used 100 respondents consisting of multiple linear regression analysis, multiple correlation coefficients, coefficient of determination, F test, and T test. As for the results of data analysis can be explained as follows:

1. Multiple Linear Regression Analysis

Multiple Linear Regression is used to determine the direct relationship between independent variables on the dependent variable. In this study using 100 respondents, namely consumers of the mighty ambassador cv . The variables contained in this study are price (X1), service quality (X2), and customer satisfaction (Y).

The explanation in each of these constant values is:

a. The value of Constata is 0,358

Value of constata which means that the independent variable price $\left(\mathrm{X}_{1}\right)$ and service quality $\left(\mathrm{X}_{2}\right)$. If the price variable $\left(\mathrm{X}_{1}\right)$ and service quality $\left(\mathrm{X}_{2}\right)$ have a value of 0 (zero) or a constant constant. Then the customer satisfaction $(\mathrm{Y})$ is equal to 0.358 . 
b. Price regression coefficient (X1) of 0.067

Price variable regression coefficient (X1) of 0.067 indicates that each increase in the price variable (X1) of one unit will result in an increase in customer satisfaction $(\mathrm{Y})$ of 0.068 with the assumption that other independent variables are constants.

c. Service quality regression coefficient (X2) of 0.513

Coefficient regression of service quality variable (X2) of 0.513 shows that each increase in service quality variable (X2) of one unit will result in an increase in customer satisfaction (Y) of 0.513 with the assumption that the other independent variables are constants.

d. Error coefficient value is 3.214

The value of std.error in this study is 3.214 from the total sample of 100 respondents, which means the error results of the regression equation from 100 respondents' data is 3.214

Analysis of the multiple correlation coefficient

The correlation coefficient $(\mathrm{R})$ in this study was used to determine the strength of the relationship between the components of the independent variable price (X1), service quality (X2) to the dependent variable consumer satisfaction (Y).

Based on table 4.13 obtained coefficient values of 0.685 shows that the relationship between the independent variable price $\left(\mathrm{X}_{1}\right)$ and service quality $\left(\mathrm{X}_{2}\right)$, to the dependent variable Consumer Satisfaction $(\mathrm{Y})$ is categorized as strong referring to the correlation coefficient interpretation table

Table 4.14 Correlation Coefficient Interpretation

\begin{tabular}{lll}
\hline & Coefficient interval & Relationship Level \\
\hline $0,000-0,199$ & & Very low \\
.200 & -0.399 & Low \\
.300 & -0.599 & Is \\
0,600 & -0.799 & Strong \\
0,800 & -0.1000 & Very strong \\
\hline
\end{tabular}

Source: Sugiyono 2018

It shows how big is the level of relationship between price independent variables $\left(\mathrm{X}_{1}\right)$ and service quality $\left(\mathrm{X}_{2}\right)$, on the dependent variable Consumer Satisfaction $(\mathrm{Y})$. the data of this study showed an $\mathrm{R}$ value of 0.686 with the coefficient interval between 0,600 - 0,799 and the level of relationship is categorized as strong.

3. Determination Coefficient Analysis (adjusted R Square)

Coefficient determination used to determine how large percentage (\%) influence of the independent variable or how much the contribution of the variable price $\left(\mathrm{X}_{1}\right)$ and service quality $\left(\mathrm{X}_{2}\right)$, to the dependent variable Consumer Satisfaction (Y adjusted R Square of 0.458 or $45.8 \%$. This means $45.8 \%$ satisfaction consumers are influenced by price (X1) and service quality (X2) whereas the remaining $54.2 \%$ is influenced by variables

a. Price variable $(\mathrm{X} 1)$

Based on the results of the study variable prices indicate that the calculated $\mathrm{T}<\mathrm{T}$ table, where the results of the calculated $\mathrm{T}$ is $0.339<1.98447$. Probability value is more than the level of significant $(\mathrm{a}=0.05)$, that is $0.735>0.05$. Based on the results, It is said that the price variable does not have a significant effect on consumer satisfaction in the mighty ambassador $\mathrm{CV}$.

b. Service Quality Variable (X2)

Based on the research results the price variable shows $\mathrm{T}_{\text {arithmetic }}>\mathrm{T}$ table, where the results of the arithmetic $\mathrm{T}$ are 6.967 $>1.98447$. The probability value is smaller than the level of significance $(\mathrm{a}=0.05)$, which is $0.000<0.05$. Based on these results that the variable service quality has a significant effect on customer satisfaction in CV Duta Perkasa. The results of this analysis indicate that service quality has a significant effect on customer satisfaction at CV Duta Perkasa .

c. F Test Results (Simultaneous)

$\mathrm{F}$ count $>\mathrm{F}$ table which is $42.884>3.09$. Based on the results of the diat as it can be said that the independent variables consisting of price and quality of service together have a significant effect to customer satisfaction by 42,884

This research goes through various stages from data instrument testing to data analysis in the form of multiple linear regression analysis which will be explained in the following discussion:

Based on the results of testing the data that has been done it can be seen that the price does not significantly influence consumer satisfaction at CV Duta Perkasa Pasuruan. . This can be seen in the T Test of prices that have a value of 0.337 and have a significant value of 0.737 . Based on the results of testing the data that has been done it can be seen that the quality of service has a significant effect on customer satisfaction at CV Duta Perkasa Pasuruan . . This can be seen in the $t$ test of Service Quality which has a value of 6.969 and has a significant value of 0,000 . 
Effect of Price and Service Quality on Consumer Satisfaction at CV Duta Perkasa Pasuruan . Based on the results of tests that have been carried out it can be seen that the variable price and service quality to customer satisfaction simultaneously (Simultaneous) affect customer satisfaction. The magnitude of the value of the influence of price and service quality variables on customer satisfaction can be seen from the F test table with a significant value of 0,000 , which means less than 0.05 . This means that the price and quality of service have a significant effect on customer satisfaction at CV Duta Perkasa Pasuruan . .

This research can provide benefits for the manager or CV Duta Perkasa Pasuruan. The important things to note by the manager of CV Duta Perkasa are as follows:

1. Price

Overall for the variable price (entrance ticket) CV Duta Perkasa get a response does not have a significant effect on customer satisfaction in CV Duta Perkasa Pasuruan. This development is done first, the price of the package, the price of the package that has been set by the company must be the same as the facilities already offered previously with everything in the field and everything can be fulfilled and also given a price discount, in addition to that the price must be frequently updated information on social media, and also improve product quality.

2. Service quality variables

Overall service quality has a significant effect on customer satisfaction or is said to be good. This happens because the quality of service provided by Duta Perkasa CV employees is in accordance with the expectations of Consumers who can provide satisfaction, this must also continue to be maintained and improved so that the quality of service in CV Duta Perkasa is maintained more service quality in the eyes of consumers, so that the quality of service provided so far does not provide a decrease in the quality of service.

\section{Conclusion}

Price variable has no significant effect on consumer satisfaction in CV Duta Perkasa Pasuruan . This happens because there are variables from this study that are more influential, namely service quality. Each increase or lowering the price of less affect customer satisfaction, essentially consumers pay more attention to the quality of the admission price they bought, despite having to pay Expensively.Variabel service quality significantly influence consumer satisfaction in CV Duta Perkasa Pasuruan. if the quality of service in CV Duta Perkasa can be maintained or improved, customer satisfaction will increase and vice versa if the quality of service decreases, customer satisfaction will decrease. So good quality service and quality can provide success in a company. Price and service quality variables in CV Duta Perkasa Pasuruan influence together (Simultaneous) on Consumer Satisfaction. So if both of them are together improved, it will increase Consumer Satisfaction

\section{Recommendations}

An easily accessible location can affect consumer satisfaction, because easily the location to be visited is easily accessible to tourists who will feel satisfied. Branding or uniqueness of CV Duta Perkasa can also affect consumer satisfaction, because CV Duta Perkasa has a good branding with the nickname Stainless steel that can affect consumer satisfaction.

\section{References}

Abdullah, Md., 2012. The influence of service quality and price on customer satisfaction, an empirical study on restaurant service in Khulna division. Study journal of finance \& accounting, Vol 3, No 4 (PP 8-11), ISSN 2222-2847.

Akbar, M, Parvez, N., 2009. Impact of service quality, trust and customer satisfaction on customer loyalty, ABAC journal. Vol. 29. No. 1 (PP 24-38), available on : http://www.journal.au.edu/abac journal/ 2009/jan09/article02_JanApr2009.pdf

Al-Tit, A. A. 2015. The effect of service and food quality on customer satisfaction and hence customer retention. Asian Social Science, 11(23), 129-139.

Canny, I. U. (2014). Measuring the mediating role of dining experience attributes on customer satisfaction and its impact on behavioral intentions of casual dining restaurant in Jakarta. International Journal of Innovation, Management and Technology, 5(1), 25-29.

Creswell, J.W. (2009) Research Design: Qualitative, Quantitative, and Moxed Methods Approaches 3rd ed. California: Sage. Print

Hasan, Ali. (2013). Marketing and Selected Cases. Jakarta: CAPS

Heir, J. F., et al. (2010). Multivariative data analysis (7th edition). New Jearsy: Pearson Education Inc.

Hussein, A. A. (2016). Service quality practices and customer satisfaction in taxi companies in Nairobi. Master's Thesis-Business Administration in Operations Management, School of Business, University of Nairobi.

Kaura, V. (2012). A link for perceived price, price fairness and customer satisfaction. Pacific Business Review International Journal, 5(6), 84-88.

Kotler, P. (2000). Marketing management: The millennium edition. Marketing Management, 23(6), $183-193$. 
Maulana, A. F. 2016. The Effect of Service quality and price costumer satisfaction PT. TOI. Jurnal Ekonomi. 7(2)

Oliver, R. L. (1993). Cognitive, affective, and attribute bases of the satisfaction response. Journal of Consume Research, 20(3), 418-430.

Prashanti, K. 2013. Human Resource Planning - An Analytical Study. Vol II. 2013. International Journal of Business Management and Invention. India

Pearson, N., 1996. Building brands directly: creating business value from customer Relationships. Macmillan Business, 20 (6), (PP 68-82)

Sofo, Francesco. 2000. Human Resources and Their Development; Human Resources Development plans. Ecyclopedia of Life Support Systems. Vol 1. Australia

Spencer,M.Lyle and Spencer,M.Signe, 1993, Competence at Work:Models for Superrior Performance, John Wily \&amp; Son,Inc,New York,USA

Tjipono, F \& G. Chandra. 2011. Service, quality \& satisfaction. Yogyakarta: Andi Offiset .

Zielke, Stephan. (2017). “The Impact of Price-Related Incidents on Store Puasty”. European Journal of Marketing, Vol. 38 (4), pp. 543-560. 